\title{
ひとつの場所のために
}

\section{For a little place}

内藤 廣 Hiroshi NAITO

株式会社内藤廣建築設計事務所
はやいものであれから 10 年が経ちました。この間のこ とに思いを馳せると様々な事がらが脳裏に浮かんできます。 衝撃的な被災の風景, それがダンプカーが走り回る騒がし い復興の風景に変わっていき，一段落するとともに，街は 新たな生を静かに育もらとしています。

われわれのような外部の人間は，ひたすらお手伝いをす ることしかできなかったわけですが，それが充分なもので あったのか，あのやり方が適切なものであったのか，まっ たく自信がありません。この間, 国や岩手県など 16 の委 員会の委員を務めました。何を言っても聞いてもらえない。 あの状況下ではしかたのないことです。ほとんどが負け戦 でした。

防潮堤，高台移転，嵩上げと区画整理，これらの組み合 わせで大方の復興がなされました。いわばドタバタのなか で現行法の枠組みの中で対応するしかなかったわけですが, もっと違ったやり方があったのではないかと思ら事も一度 ならずありました。法律や縦割り行政の壁に阻まれて突破 できなかった事がらは山のよらにあります。

個人的には，こうした忸怩たる思いが復興祈念公園を作 り上げる上でのエネルギーになっています。せめてあの場 所は，被災された方たちも含めて多くの人が納得のいく場 所にしたかった。

わが国は災害が多発する国土を持っています。そう考え れば，平時に緊急事態への備えを議論して法整備をしてお くべきだと思っています。今時のコロナ禍で議論されてい ることの多くは, 3.11 の時に議論したこととさして変わり はありません。非常時の個人の権利の扱い方, 人権の扱い 方，共同体のあり方，どれも本質的には同じことです。非 常時の対応が日常に戻る復元のあり方を変えるはずです。

これらが 10 年を経て日々頭をよぎることです。しかし， それでも 3.11 の被災地では数々の新たな営みが始まって います。それが豊かなものになることを願ってやみません。

さて, 高田松原津波復興祈念公園は, 復興の喧騒の中で 計画され, その最終盤化設されました。長さ $4 \mathrm{~km}$ に伸 びる高さ $12.5 \mathrm{~m}$ の長大な防潮堤は, 全ての計画の大前提 のようなものです。千年に一度程度の L2 規模の津波は防
げないけれど, 百年に一度程度の L1 規模の津波には対応 できる，といらことになっています。しかし，津波は震源 や湾の地形で千変万化し, 跳衫返されて生じる干渉波は予 測不可能です。自然の振る舞いは基本的には計り知孔ない のです。それを忘れてはいけません。立派な防潮堤だけど， たぶん大丈夫だろう，くらいの感覚で受け止めておくのが よいのだと思います。したがって，全体計画では発災後の 避難が前提になっています。どのように高台や山に逃げる ことができるのか，どのくらい時間がかかるのか，などを 検証しながら園路を決め, 建物も水没を前提に構造計算を しています。

広大な県営の公園の一部に設定された国営祈念公園の敷 地は，防潮堤の背後の海の見えない低地にあります。嵩上 げされた市街地からも，ほとんど海を見ることができませ ん。この街を訪れた人は，美しい広田湾を見ないで街を通 り過ぎることになります。海が遠くなったのです。

追悼祈念の場を作るに際して，やはりどうしても訪れた 人たちに海を見てもらいたいと思いました。悲惨な出来事 を引き起こした海は, 日常的にはこの上なく美しい風景を 提供してくれます。それを見ていただき，思いを馳せてい ただく，そして一時だけあの日を思い出していただく，そ んな願いを託したのが防潮堤の上の小さな場所，「海を望 む場」です。公園も展示施設も道の駅も震災遺構も, そう した道具立てのすべてはこの小さな場所のためにあるいっ てもよいと思います。

遙か遠くの未来まで記憶を継承するために，市が大決断 をして残すことになった震災遺構である旧気仙中学校, 一 本松, ユースホステル, 道の駅だったタピック 45 , さら に遠くの下宿定住促進住宅まで， $2 \mathrm{~km}$ もの長さになります。 しかし，まだそれらを見たくない地元の方もたくさん㧍ら れます。海に近寄机ないといら方もいます。津波の傷は深 く，心の見えないところに無数に潜んでいます。

遺構を残すのであ机ば，これらを柔らかに包み込むよう なものが是非とも必要だと思っていました。「大きな包摂線」 を描き，これらを癒やすように大きなランドスケープでゆ るやかに包み込むことを考えました。さらにこの包摂線に 抱かれるように「小さな包摂線」を描いて，国立の追悼工 
リアになる当該敷地をさらに包み込むようにしました。

このふたつの包摂線で包み込まれた当該敷地の中央から 広田湾の中心に向から線を引くと，それは奇跡的に防潮堤 とほぼ直角に交差することがわかったので，これを「祈り 軸」としました。一方，隣接する遺構のタピックから，博 物館機能を持つ伝承施設, 人々の暮らしの場としての新し い道の駅へ，祈りの軸と直交する軸線を描くことが出来ま す。被災，復興，そして未来へ，この軸線に意味付けをす ることができます。これを「復興の軸」とし，「祈りの軸」 と交叉する点を中心に, 公園全体のゲートとなるような建 物を配置しました。(口絵資料 図 1-5)

この交叉部には水盤を設けて上部から光が射すようにし， ここで来場者が気持ちを切り替えられるようにしています。 ここから防潮堤に向から逆 $\mathrm{V}$ 字型の広場を作り, その中 央正面に欅の列植の塊を配置しました。ここが日常的な喧 噪からしだいに離れて, 気持ちを整えていく場所になって います。広場は緩やかな下り勾配になっていて, その先に 献花をする場所があります。さらに進むと, 少し上り勾配 になって橋を渡ります。その先に階段があり「海を望む場」 へと人を導いていきます。この $300 \mathrm{~m}$ の間に，これらの幾 つもの違った空間体験が仕組まれています。帰り道,「海 を望む場」から振り返ると, これらの構成が分かるように なっています。

建物は RC 造で，一部鉄骨造です。 $\mathrm{RC}$ 造の小屋裏部分 には，空のない部屋を設けて万が一の場合に備えています。 建物の主要な表情を形成している上部の白い外壁は, 高い 精度を出すために PCa のカーテンウォールで構成し, RC の躯体から $1 \mathrm{~m}$ ほど持ち出しています。アプローチ側の PCa には，追悼の気持ちを込めて 18434 個のちいさな孔 があけられています。これは 2018 年時点での亡くなられ た方と行方不明の方の数です。具体的に壁を眺めると，い
かに多くの方が亡くなられたか，数字の意味を実感するこ とができます。夜になると内側の壁が点灯され，この孔か らやさしい光が漏孔出し, 建物からの密やかな哀悼の意を 表しています。

多くの人が訪れ，道の駅と伝承施設に立ち寄り，ほとん どの人が $300 \mathrm{~m}$ ほど離れた防潮堤の上のちいさな場所, 海 に対して思いを馳せる「海を望む場」に足を運んでくれま す。公園全体はまだ未成熟です。今は二つの軸線が際立つ ていますが，やがて包摂線を構成する樹木や灌木が育って いき，より柔らかな場が広がっていくことを期待していま す。

以上述べたのことは，あくまでも計画上の構想の組み立 て方です。防潮堤の可否も含めて，あの惨事に対してこの 時代がどのように向き合ったのかを，公園全体で伝える場 になったのではないかと思っています。

公園全体でメッセージを伝えるようにするには，諸官庁 の協力が不可欠でしたし，なによりデザイン的な一貫性を 実現するに際しては, 平野勝也東北大准教授と篠沢健太工 学院大学教授との共同作業がおおきな役割を果たしました。 津波がご専門の首藤伸夫東北大名誉教授からは, 貴重なア ドバイスと精神的なご支援をいただきました。また，構想 委員会の中井検裕委員長はもとより, 基本構想検討会の涌 井史郎委員長，発災時に東北地方整備局長として陣頭指揮 を執られた徳山日出男元国交省事務次官，具体化するに当 たっての推進力となった脇坂隆一元東北国営公園事務所長 のご支援とご理解があったことを付記しておきたいと思い ます。

\section{参考資料}

1）口絵資料 図 $1-1,1-2,1-3$ 